THE RING 35 (2013) DOI 10.2478/ring-2013-0003

\title{
THE RINGING SITE IN JERICHO (PALESTINE) \\ - DEVELOPMENT OF BIRD MIGRATION \\ AND PARASITOLOGICAL RESEARCH ON THE GREAT \\ RIFT VALLEY FLYWAY
}

\author{
Simon Awad, Izabella Rząd, Przemysław Busse
}

\begin{abstract}
Awad S., Rząd I., Busse P. 2013. The ringing site in Jericho (Palestine) - development of bird migration and parasitological research on the Great Rift Valley flyway. Ring 35: 55-63.

A new research project near Jericho in the Jordan Valley (Palestine) was launched on 10 September 2013, work continued until October 23rd 2013. Standard ornithological work and bird ringing work was conducted using mist nets situated in an oasis type habitat of Wadi Qelt surrounded by palm plantations. The field methods followed the SEEN (SE European Bird Migration Network) standards that include apart from ringing of captured birds, also several measurements (wing length, tail length, wing formula) and scores (fat load and body mass), as well as the studies on the directional preferences of migrants using round, flat orientation cages. Ornithological research was enhanced by parasitological studies analysing migratory birds (hosts) - helminths relations during migration period of the former. This was a part of complex studies covering the Middle East and north African ringing sites. Altogether 481 individuals of birds representing 59 species were ringed and about 50 were retrapped. The most interesting was relatively high share of Masked and Red-backed shrikes as well as good number of birds of local species as Dead Sea Sparrows and introduced Indian Silverbills.
\end{abstract}

S. Awad, Environmental Education Center (EEC) of the Evangelical Lutheran Church in Jordan and the Holy Land (ELCJHL), Bethlehem, Palestine, E-mail: eec@p-ol.com; sija9 @yahoo.com; I. Rząd, University of Szczecin, Poland, Bird Migration Research Foundation, Przebendowo 3, 84-210 Choczewo, Poland, E-mail: izarzad@gmail.com; P. Busse, Bird Migration Research Foundation, E-mail: busse@wbwp-fund.eu

Publication appointed to the SE European Bird Migration Network papers

Key words: autumn migration, migration dynamics, passerines, Jordan Valley, ringing, directional preferences, internal parasites, helmints 


\section{INTRODUCTION}

Although Palestine covers quite small area compared to some countries in the world, it is in a significant geographic location, with a wide range of temperature, rainfall and topography. In addition, the country touches several different civilizations, religions and cultures. Palestine profits greatly from this biodiversity and can be considered as a natural museum.

Jericho sits between Mt. Nebo in the East, the Central Mountains to the West and the Dead Sea to the South. It is located in the Jordan Rift Valley, which is a part of the Great Rift Valley. In addition to these natural fortifications, Jericho also benefited from natural irrigation afforded by the Jordan River to the West and from underground tributaries from the Central Mountains. This irrigation resulted in teeming plant life and helped to transform Jericho into a flowing sea of green in an otherwise barren desert. Jericho is the oldest city in the world and is estimated to be 10 thousand years old. Besides being old, Jericho is also one of the "lowest" cities in the world as it is located about $250 \mathrm{~m}$ below sea level. It lies within an agricultural land, mixed with semi-arid to arid areas. The flora region is considered to be a Sudanian Penetration Region: winter is short and warm and summer is long, hot and dry. It is famous for its vegetables and palm trees.

Jericho is located in the Jordan Rift Valley, which is considered important bird area according to Birdlife International, as it is the second most important flyway for migratory birds in the Palaearctic, especially for soaring birds and the most important route of the Central/Eastern Europe-Africa flyways.

\section{THE STUDY AREA AND THE PERIOD OF WORK}

Environmental Education Center (EEC) runs two ringing stations in Palestine and one of them is the Jericho Ringing Station ( $\left.31^{\square} 51^{\prime} \mathrm{N}, 35^{\square} 27^{\prime} \mathrm{E}\right)$. It is located in Jericho City, in the Jericho District, which lies in the Jordan Valley north of the Dead Sea and is characterized by its semi-arid to arid climate, but can also be considered an oasis given its natural springs and availability of surface water.

The main study area ("Jericho I") is located in the southern part of Wadi Qelt seasonal stream and also near Wadi Hajla and the adjacent wadi, $2 \mathrm{~km}$ to the north. In addition, the study area is located south of the main dump site for Jericho. This area is a rich oasis (Figs. 1-2) with a high abundance of: Ziziphus spina-christi, Tamarix aphylla, Acacia sp., Atriplex lasiantha, Atriplex halimus and Datura innoxia. During three days another location close to the main site (Jericho II $-2 \mathrm{~km}$ away) was also used for pilot on bird migration.

Although the site is close to the Jordan Valley border and the Jordan River, it appears to be a good path for migration of the wildlife from west to east, or vice versa, allowing Gazella sp., Lepus capensis, Vulpes vulpes, Hyaena hyaena, Hystrix indica and Herpestes ichneumon to cross the valley. 


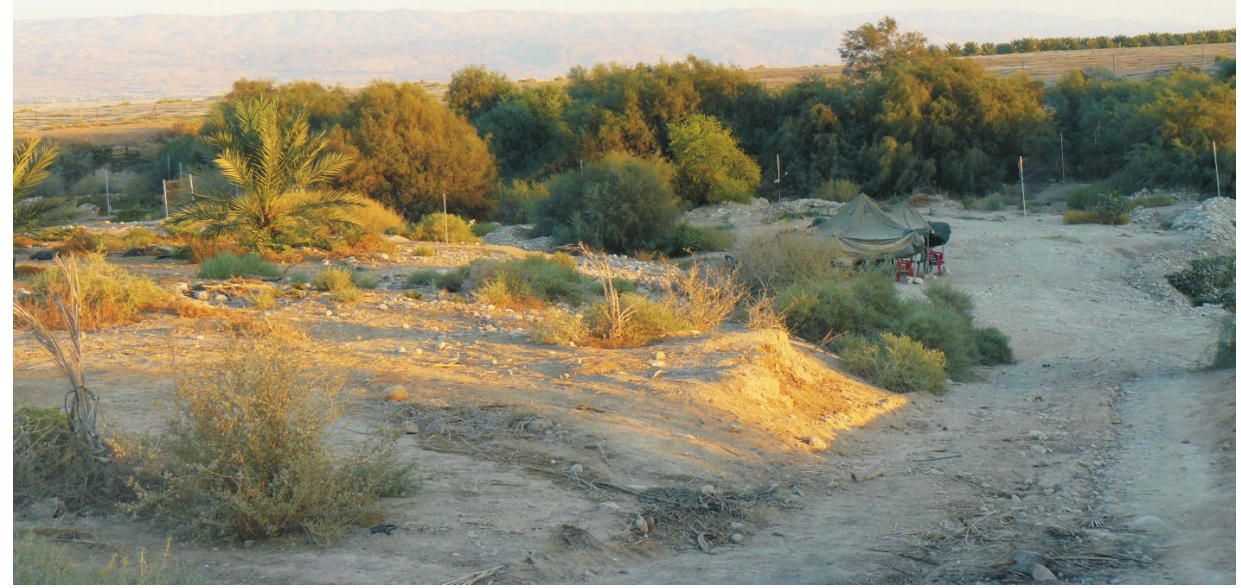

Fig. 1. The general view of the ringing site in SE direction - the Jordanian hills are visible on the horizon. Photo P. Busse

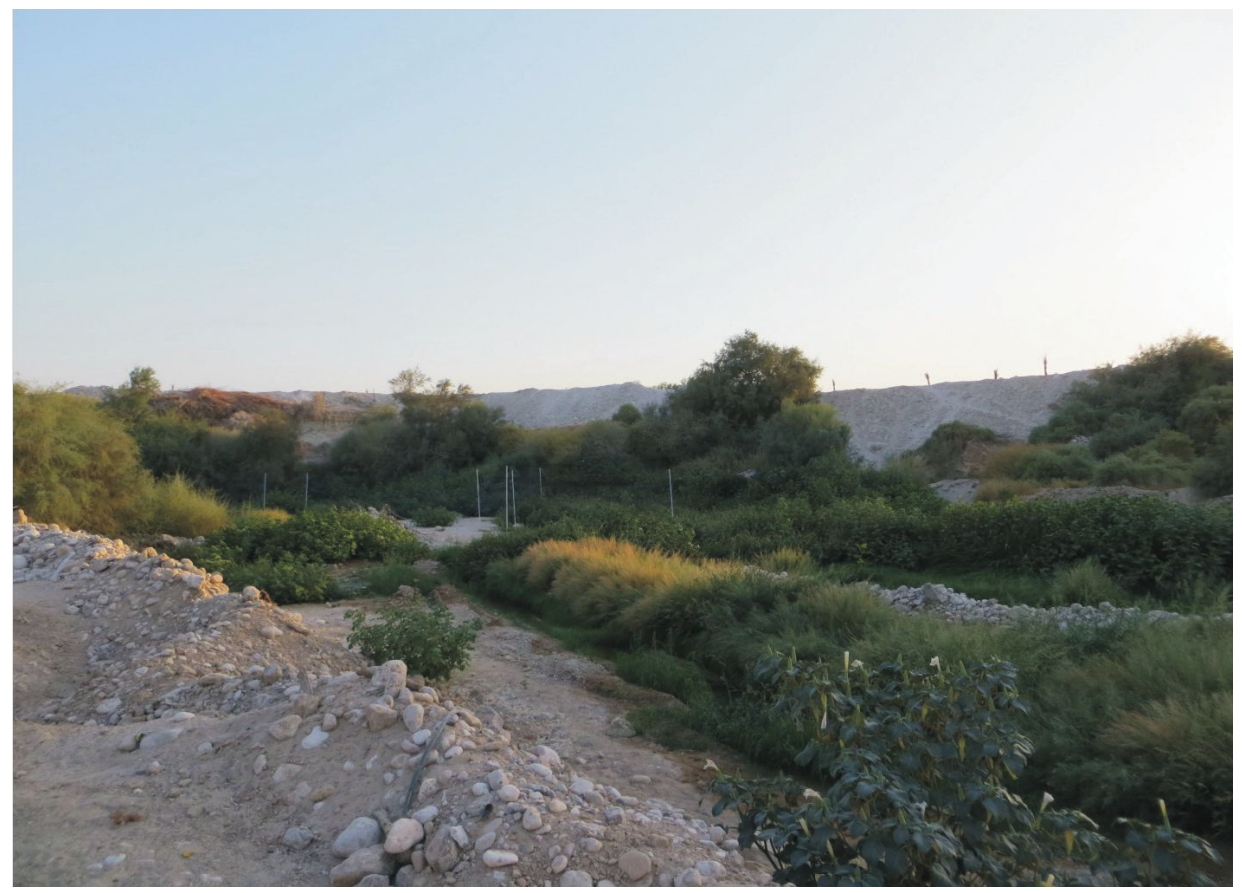

Fig. 2. Close-up of the ringing area. Photo S. Awad 
The EEC, in cooperation with the SEEN (SE European Bird Migration Network), the Bird Migration Research Foundation Przebendowo and the Arab Development Society, set up a research project in Jericho area that was run from 10th September to 23rd October 2013.

\section{THE BASIC ORNITHOLOGICAL RESULTS}

In standardized ornithological/bird ringing programme 11 mist-nets (each $12 \mathrm{~m}$ long) and 25 nets (each $7 \mathrm{~m}$ long) were used. They were distributed randomly along the wadi. The routine of the work followed the SEEN standards (Busse 2000), including biometric measurements (wing length, tail length, wing-formula, fat scoring and weighing). Retraps were checked for the fat score and weighed. Additionally migrants were tested for directional preferences with the Busse's orientation flat cage. Because of a very high temperature in the mid-day, the nets were closed at $11.00 \mathrm{a} . \mathrm{m}$. of the local time and then opened after 4.00 p.m. They stayed open during the night, but a few of them were closed just after the sunset, because of the activity of fruit-eating bats. During the day nets were controlled every hour and more frequently when the temperature exceeded $35^{\circ} \mathrm{C}$. No birds were lost due to the heat during the day. A few dead individuals were recorded because of the activity of shrikes that killed other birds when captured. These dead individuals were used for the parasitological studies that were the part of the research program (see below).

421 birds of 47 species (Table 1) were captured and ringed at the main site, while around a hundred individuals were retrapped. The total number of captured birds was not so high, but they represented a relatively high variety of species. The number of shrikes - both Masked and Red-back Shrikes - was particularly worth to point out. This number is of the highest recorded for shrikes on the bird ringing SEEN stations in the Middle East. Moreover quite low number of migrants captured in autumn compared to spring is typical in this region (Table 2 - own data). Therefore it could be expected that spring ringing there could be much more effective.

Daily number of birds captured in Jericho fluctuated much (Fig. 3) and it seems that the period of work did not cover the whole period of autumn migration. When comparing the results recorded in other stations in the region, it seems that this pilot study started too late in the season, as well as ended too soon - we did not capture late migrants as the Chiffchaff and Bluethroat that migrate late in the season and even can winter here.

As two species of shrikes were relatively numerous, we compared their migration dynamics over the season (Fig. 4) - it looks that these two similar species tend to avoid to migrate in the same period as most probably they are competitors. This observation could encourage to further behavioral studies on these species.

The number of the directional preferences' tests was not too high (138). Because of the heat - we had to stop conducting tests when the temperature reached $32-33^{\circ} \mathrm{C}$. More detail analyses - species by species - are not possible at the moment. However, it is interesting that the general pattern (Fig. 5) is complementary to the results recorded in Azraq, Jordan in 2008 (Stępniewska et al. 2011). One need to remember 
that the reverse headings (in northern sectors of the wind rose in autumn) shown in the graph have the same information value as the southern sector directions (e.g. Formella and Busse 2002, Zehtindjiev et al. 2003, Stępniewski et al. 2011).

Table 1

List of species captured and ringed in Jericho in autumn 2013

(a few species were not ringed, because of lack of appriopriate rings)

\begin{tabular}{|c|c|c|c|c|c|}
\hline Code & Scientific name & English name & \multicolumn{2}{|c|}{\begin{tabular}{|l|l|} 
Jericho I & Jericho II \\
\end{tabular}} & Total \\
\hline \multicolumn{6}{|c|}{ Captured and ringed } \\
\hline ACR.ARU & Acrocephalus arundinaceus & Great Reed Warbler & 1 & & 1 \\
\hline ACR.SCH & Acrocephalus schoenobaenus & Sedge Warbler & 9 & & 9 \\
\hline ACR.SCI & Acrocephalus scirpaceus & Reed Warbler & 9 & & 9 \\
\hline ACR.RIS & Acrocephalus palustris & Marsh Warbler & 5 & & 5 \\
\hline ANT.TRI & Anthus trivialis & Tree Pipit & 1 & & 1 \\
\hline CAL.TEM & Calidris temminckii & Temminck's Stint & 1 & & 1 \\
\hline CER.GAL & Cercotrichas galactotes & Rufous Bush Robin & 1 & & 1 \\
\hline EMB.CAE & Emberiza caesia & Cretzschmar's Bunting & 5 & & 5 \\
\hline EMB.HOR & Emberiza hortulana & Ortolan Bunting & 1 & & 1 \\
\hline GAL.CRI & Galerida cristata & Crested Lark & 1 & & 1 \\
\hline GAL.CHL & Gallinula chloropus & Moorhen & & 10 & 10 \\
\hline HIP.PAL & Hippolais pallida & Olivaceous Warbler & 8 & & 8 \\
\hline HIR.RUS & Hirundo rustica & Barn Swallow & 2 & 1 & 3 \\
\hline JYN.TOR & Jynx torquilla & Wryneck & 4 & & 4 \\
\hline LAN.COL & Lanius collurio & Red-backed Shrike & 24 & 1 & 25 \\
\hline LAN.NUB & Lanius nubicus & Masked Shrike & 37 & & 37 \\
\hline LOC.LUS & Locustella luscinioides & Savi's Warbler & 5 & & 5 \\
\hline LON.MAL & Lonchura malabarica & Indian Silverbill & 46 & & 46 \\
\hline LUS.LUS & Luscinia luscinia & Thrush Nightingale & 2 & & 2 \\
\hline LUS.SVE & Luscinia svecica & Bluethroat & 10 & 6 & 16 \\
\hline MER.ORI & Merops orientalis & Green Bee-eater & 8 & 1 & 9 \\
\hline MOT.FLA & Motacilla flava & Yellow Wagtail & 1 & & 1 \\
\hline MUS.STR & Muscicapa striata & Spotted Flycatcher & 5 & & 5 \\
\hline OEN.HIS & Oenanthe hispanica & Black-eared Wheatear & 2 & & 2 \\
\hline OTU.SCO & Otus scops & Scops Owl & 2 & & 2 \\
\hline PAS.DOM & Passer domesticus & House Sparrow & 5 & & 5 \\
\hline PAS.HIS & Passer hispaniolensis & Spanish Sparrow & 95 & 2 & 97 \\
\hline PAS.MOA & Passer moabiticus & Dead Sea Sparrow & 16 & 11 & 27 \\
\hline PHO.PHO & Phoenicurus phoenicurus & Redstart & 2 & & 2 \\
\hline PHY.COL & Phylloscopus collybita & Chiffchaff & 4 & & 4 \\
\hline PHY.LUS & Phylloscopus trochilus & Willow Warbler & 43 & 1 & 44 \\
\hline PRI.GRA & Prinia gracilis & Graceful Prinia & 1 & 1 & 2 \\
\hline PYC.XAN & Pycnonotus xanthophygos & Yellow-vented Bulbul & 19 & & 19 \\
\hline RAL.AQU & Rallus aquaticus & Water Rail & 1 & & 1 \\
\hline RIP.RIP & Riparia riparia & Sand Martin & 1 & & 1 \\
\hline SAX.OLA & Saxicola rubicola & Stonechat & 1 & & 1 \\
\hline
\end{tabular}




\begin{tabular}{|c|c|c|c|c|c|}
\hline Code & Scientific name & English name & Jericho I & Jericho II & Total \\
\hline SAX.TRA & Saxicola rubetra & Winchat & 3 & & 3 \\
\hline STR.DEC & Streptopelia decaocto & Collared Dove & & 1 & 1 \\
\hline SYL.ALA & Sylvia melanocephala & Sardinian Warbler & 2 & & 2 \\
\hline SYL.ATR & Sylvia atricapilla & Blackcap & 20 & & 20 \\
\hline SYL.BOR & Sylvia borin & Garden Warbler & 4 & & 4 \\
\hline SYL.COM & Sylvia communis & Whitethroat & 2 & & 2 \\
\hline SYL.CUR & Sylvia curruca & Lesser Whitethroat & 7 & 1 & 8 \\
\hline SYL.HOR & Sylvia hortensis & Orphean Warbler & 1 & & 1 \\
\hline TRI.GLA & Tringa glareola & Wood Sandpiper & 2 & & 2 \\
\hline TRI.OCH & Tringa ochropus & Green Sandpiper & 1 & & 1 \\
\hline VAN.SPI & Vanellus spinosus & Spurn Lapwing & 1 & 1 & 2 \\
\hline \multicolumn{3}{|c|}{ Total ringed } & 421 & 37 & 458 \\
\hline \multicolumn{6}{|c|}{ Captured but not ringed } \\
\hline ALC.ATT & Alcedo atthis & European Kingfisher & 9 & & 9 \\
\hline ANA.CRE & Anas crecca & Teal & 1 & & 1 \\
\hline BUR.OED & Burhinus oedicnemus & Stone Curlew & 1 & & 1 \\
\hline EGR.GAR & Egretta garzetta & Little Egret & 1 & & 1 \\
\hline GAL.GAL & Gallinago gallinago & Snipe & 1 & & 1 \\
\hline HAL.SMY & Halcyon smyrnensis & White-throated Kingfisher & 3 & & 3 \\
\hline LAN.EXC & Lanius excubitor & Great Grey Shrike & 2 & & 1 \\
\hline OEN.CAP & Oena capensis & Namaqua Dove & 1 & & 1 \\
\hline ORI.ORI & Oriolus oriolus & Golden Oriole & 1 & & 1 \\
\hline POR.ANA & Porzana porzana & Spotted Crake & 1 & & 1 \\
\hline STR.TUR & Streptopelia turtur & Turtle Dove & 1 & & 1 \\
\hline TUR.SQU & Turdoides squamiceps & Arabian Babbler & 1 & & 1 \\
\hline \multicolumn{3}{|c|}{ Total not ringed } & 23 & & 23 \\
\hline \multicolumn{2}{|l|}{ Grand total } & & 444 & 37 & 481 \\
\hline
\end{tabular}

\section{Table 2}

Catching efficiency at some ringing sites along the Great Rift Valley. Days - number of days included in a season, Ringed - number of ringed birds, Per day - average number of birds captured per day. Est. - estimation for Jericho in spring.

\begin{tabular}{|l|l|c|c|c|c|c|c|}
\hline \multirow{2}{*}{ Ringing site } & \multirow{2}{*}{ Location } & \multicolumn{3}{c|}{ Autumn } & \multicolumn{3}{c|}{ Spring } \\
\cline { 3 - 8 } & & Days & Ringed & Per day & Days & Ringed & Per day \\
\hline Jericho, Palestine & inland & 41 & 421 & 10.3 & & & Est. 42-93 \\
\hline Azraq, Jordan & inland & 40 & 276 & 6.9 & 41 & 2634 & 64.2 \\
\hline Hurghada, Egypt & coastal & 24 & 868 & 36.1 & 66 & 6094 & 92.3 \\
\hline Wadi Gemal, Egypt & coastal & 41 & 230 & 5.6 & 44 & 1046 & 23.8 \\
\hline
\end{tabular}




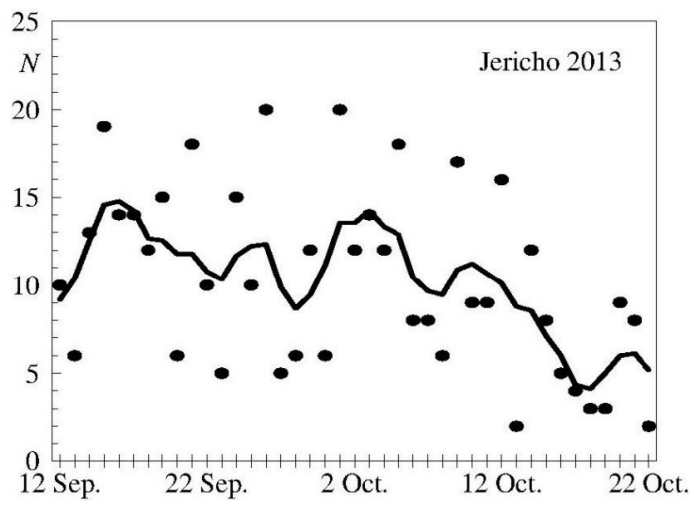

Fig. 3. Bird capturing dynamics in Jericho 2013. Dots - daily captures, line - the daily data smoothed using moving average.

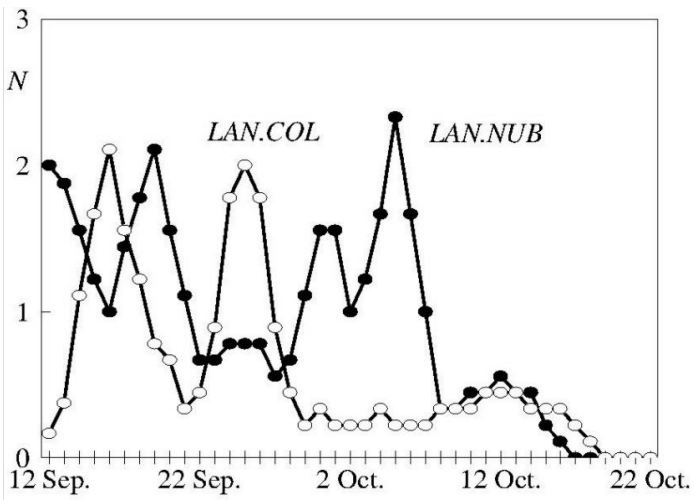

Fig. 4. Capturing dynamics of shrikes: LAN.COL - Red-backed Shrike (Lanius collurio), LAN.NUB - Masked Shrike (L. nubicus).

\section{PARASITOLOGICAL PROBLEMS IN THE WORK}

Parasite fauna of birds migrating from the breeding grounds to the winter quarters changes according to this cyclic phenomenon (Dogiel 1962), because migrating hosts could transfer parasites from one geographical area to the distant ones (Niewiadomska and Pojmańska 2004). These transferred parasites are potentially dangerous to the local fauna when they find appropriate conditions (climatic and biotic, as e.g. potential new intermediate or final hosts) within new territory. This problem is wellknown in the studies on fish fauna (e.g. Grabda-Kazubska 1974), but is very rarely analysed in birds. According to the research conducted in Poland at least 20 species of helminthes were recorded in birds durimg the period of their migration (Pojmańska et al. 2000, Okulewicz A. 2013), but a number of parasites did not represent any species regularly living in this country during the breeding time of the analysed 


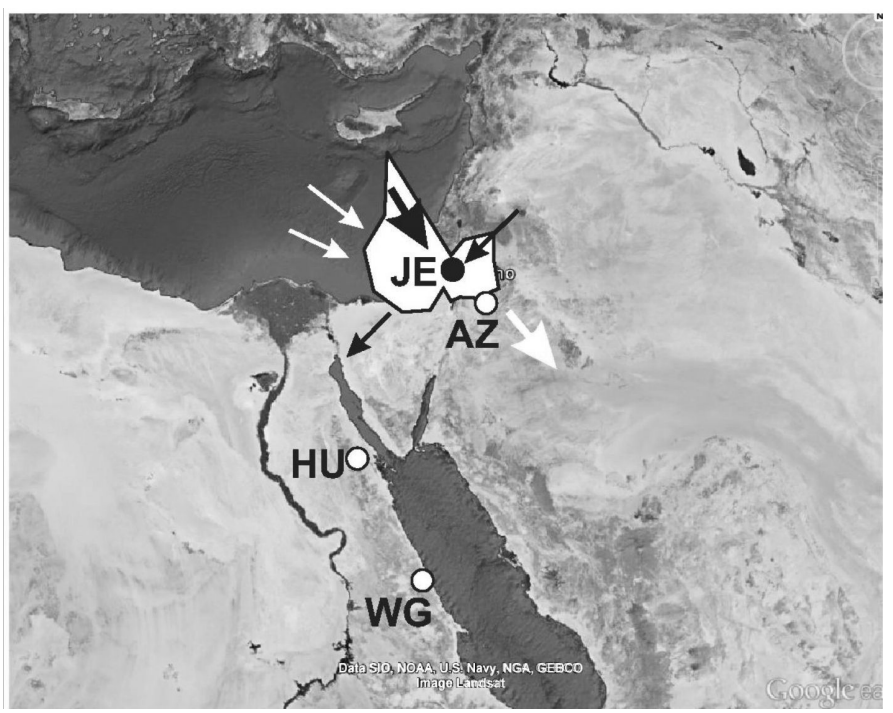

Fig. 5. General pattern of the headings of birds tested in the orientation cage (white area) in Jericho; the map of the region is given as the background. Arrows illustrate assumed directions of migration. Circles - location of ringing sites mentioned in the text and in Table 2: JE - Jericho (Palestine), AZ - Azraq (Jordan), HU - Hurghada (Egypt), WG - Wadi Gemal (Egypt).

bird species. Some of them were suspected to be transferred from the winter quarters of migrating birds (Machalska 1980, Okulewicz J. 1993, Okulewicz A. 2013).

Our studies on helminth parasites in Jericho, as well as along the eastern bird migration flyway (Jordan, Israel, Egypt) are intended as interdisciplinary, ornithological and parasitological, studies on the host-parasite relations during the long distance migration of birds and exchange of parasites on the route between local and migrating populations. This means to study faunistics and ecological problems of the helminth assemblages on the background of bird migration. The practical solution is to connect the parasitological work and the bird migration and ringing activity. This gives a unique possibility to study parasites and their hosts during the highly demanding (particularly physiologically) period for the latter. The Middle East is the best area to conduct such complex research as it is close to large natural geographical barriers for migrating birds (Mediterranean Sea, Sahara Desert). Moreover anthropogenic elements in these dry areas - water cleaning plants and rubbish dumps open new contact biotopes for both birds and their parasites, that have never existed before. This could have an influence even on health problems of the human population and its farming products.

Till now the studies were performed in Azraq, Jordan (spring 2012), Aswan, Egypt (autumn 2012) and at present in Jericho and Talitha Kumi, Palestine. 43 individuals of dead migrants were inspected (Acrocephalus scirpaceus, A. schoenobaenus, Sylvia atricapila, S. hortensis, S. curruca, S. communis, S. borin, Phyloscopus colybita, P. trochilus, Locustella luscinioides, Hirundo rustica, Muscicapa striata, Otus scops,) and 15 local birds (Acrocephalus stentoreus, Athene noctua, Streptopelia senegalensis, Pas- 
ser domesticus, Lonchura malabarica). The last species mentioned is a very special one for Jericho area as it was introduced here from India.

Altogether $40 \%$ of all these birds were infested by helminths representing different systematic groups, i.e.: 48 Digenea parasites, over 50 Cestoda, 6 Nematoda and 31 Acanthocephala were recorded. At the moment identification and evaluation of all these specimens are in progress.

The parasitological study is expected to be continued along with the development of the bird migration studies planned in Palestine and along the Great Rift Valley.

\section{REFERENCES}

Busse P. 2000. Bird Station Manual. Gdańsk, University of Gdańsk.

Dogiel V. A. 1962. General parasitology. Leningrad, Izdatielstvo Leningradskogo Univiersitieta. (In Russian).

Formella M., Busse P. 2002. Directional preferences of the Reed Warbler (Acrocephalus scirpaceus) and the Sedge Warbler (A. schoenobaenus) on autumn migration at Lake Druzno (N Poland). Ring 24, 2:15-29.

Grabda-Kazubska B. 1974. Clinostomum complanatum (Rudolphi, 1819) and Euclinostomum heterostomum (Rudolphi, 1809), their occurrence and possibility of acclimatization in artificially heated lakes in Poland. Acta Parasitologica Polonica 22: 285-293.

Machalska J. 1980. Helmint fauna of birds of the genus Turdus examined during their spring and autumn migration. I. Digenea. Acta Parasitologica Polonica 27, 18: 153-172.

Niewiadomska K., Pojmańska T. 2004. Organizmy pasożytnicze-dlaczego należy monitorować ich wystepowanie. Biuletyn Monitoringu Przyrody 1/2004 (5): 43-51. (In Polish)

Pojmańska T., Niewiadomska K., Okulewicz A. 2007. Pasożytnicze helminty Polski. Gatunki, żywiciele, biate plamy. 360 pp. Warszawa, Polskie Towarzystwo Parazytologiczne (In Polish).

Okulewicz A. 2013. New records of nematodes imported by migratory passerines. Annals of Parasitology 59, supplement 52 .

Okulewicz J. 1993. Przywry ptaków Dolnego Ślaska. IV. Przedstawiciele rodzaju Mosesia (Pleurogenidae, Trematoda) - nowy element parazytofauny ptaków wróblowatych Dolnego Ślaska. Wiadomości Parazytologiczne 39: 39-47 (In Polish).

Stępniewska K., El-Hallah A., Busse P. 2011. Migration dynamics and directional preferences of passerine migrants in Azraq (E Jordan) in spring 2008. Ring 33, 1-2: 3-25.

Stępniewski K., White M. L. J., Megalli M. 2011. Autumn migration of passerines in Bahariya oasis, Egypt - where do they come from and where do they go? Ring 33, 1-2: 27-36.

Zehtindjiev P., Ilieva M., Ożarowska A., Busse P. 2003. Directional behaviour of the Sedge Warbler (Acrocephalus schoenobaenus) studied in two types of orientation cages during autumn migration - a case study. Ring 25, 1-2: 53-63. 